\title{
A Perpetuity of Lesser Emptiness: The Social Space of the Postcolonial Small Town and Vinod Kumar Shukla's Naukar kī kamīz
}

\author{
Philipp Sperner (D)
}

\begin{abstract}
The article provides an analysis of the spatial configuration of the Hindi novel Naukar ki kamīz by Vinod Kumar Shukla (translated into English as The Servant's Shirt). In highlighting the argumentative and structural similarities between the content of the novel and various concepts of social space and literary spatiality developed by Catherine Régulier, Henri Lefebrve, Edward Soja, Mikhail Bakhtin, and others, the article proposes to read the novel not only as a rare example of a detailed engagement with the social space of a postcolonial small town, but also as a text that provides a useful method and indeed a theory for the analysis of such a small town and its literary representation.
\end{abstract}

Keywords: Vinod Kumar Shukla, Hindi literature, India, small town, social space, urban, Lefebvre, rhythmanalysis

\section{Introduction: A Wider Scope for Considerations of Urbanity ${ }^{1}$}

What constitutes the specific character of a small town? How is the social space of such a town different from those of larger cities or villages? And where is the postcolonial small town located within the planetary grid of a globalized economy? Vinod Kumar Shukla's novel Naukar kī kamīz (published in Hindi in 1979 and translated into English as The Servant's Shirt in 1999) touches upon all these questions and several more. What makes the novel particularly relevant for literary studies, however, is its acute sensibility for the intricate entanglement of social and spatial relations. The novel offers a detailed observation and literary analysis of a small town in northern India in the 1970s by

Philipp Sperner is a doctoral student at Ludwig Maximilian University of Munich, where he is currently working on a German Research Foundation (DFG)-funded research project that looks at friendship narratives in Indian fiction and explores the political imaginary of democracy under the conditions of postcoloniality. His research interests include global intellectual history, postcolonial and political theory, deconstruction, and twentieth-century Hindi literature. (Email: philipp.sperner@posteo.net)

1 I would like to thank Francesca Orsini for her detailed and encouraging comments on a very early version of this paper several years ago. More recently, Brigitte Rath and Charlotte Bomert provided numerous important insights and critical remarks for which I am immensely grateful. Thanks also to the two anonymous reviewers and especially to Ato Quayson, who was as attentive and encouraging an editor as one could wish for. 
focusing on the everyday life and struggle of a lower-middle-class couple. Space in the novel appears not as the prior given ground of action and narrative but as a social space that is always already socially constituted. Vice versa, the novel also depicts all forms of social relations as necessarily shaped through the space in which they occur. Spatial metaphors and ideas are therefore ubiquitous in Naukar ki kamiz. They do not only structure the relationships between the characters but even permeate the mentality and reasoning of the protagonist, Santu Babu:

I opened the door and peered inside as one peers inside an empty can whose lid one has pried off. If emptiness was a substance our house was full of it. There was nothing else in the house besides emptiness. I entered the house as a greater emptiness enters the lesser. ${ }^{2}$

The distinct poetics that the novel exhibits function via a combination of spatial metaphors for social relations (emptiness, peering inside a lidless can, etc.) and a detailed description of the social spaces the characters inhabit. Both of these dimensions of Shukla's spatial poetics are kept together by the space of the postcolonial small town, which serves as the setting and background of the novel as well as the distinct social environment that Santu Babu and with him the novel explores and describes. ${ }^{3}$ The distinct characteristic of Naukar kī kamizz that makes it particularly interesting for an engagement with the literary space of the postcolonial small town is that its spatial poetics rely on a fusion of two usually distinct aspects of (literary) space. On a basic level, the novel-like any other-contains representations of space or literary reproductions of places. It produces space. On another level, the novel also offers a scattered and nonsystematic but nonetheless comprehensive and complex analysis of the very space it produces and represents, that is, it analyses and theorizes space.

The analysis of space in the novel represents not a different textual layer inserted in the literary text but takes place in and through the narrative of Santu Babu's daily life. As I want to show, this literary analysis of space entails a very specific theoretical dimension. It stresses the need for a different notion of "theory" that is not limited to its current Eurocentric conception as abstract and universal thought but more encompassing of different modes of intellectual engagement-a theory that is not conceived as an act of

2 Vinod Kumar Shukla, The Servant's Shirt (New Delhi and London: Penguin, 1999), 205; Vinod Kumar Shukla, Naukar Kī kamīz (Naī Dillī: Rājkamal Peparbaiks, 1994), 209. This and all further quotations from Naukar $k \bar{l} k a m \bar{i} z$ are taken from the English translation by Satti Khanna. Instead of also providing the original Hindi text, the footnotes include references to the respective page numbers of the Hindi edition in square brackets.

3 It should be noted that Naukar kī kamiz is in no way the only or first Hindi literary narrative that is set in a small town. It is certainly true that the "Indian village" has occupied a privileged position as the quintessential social space of Indian literary narratives-either as the locus of a Gandhian ideal of peaceful coexistence in the early twentieth century or as the paradigmatic space of "backwardness," oppression, and destitution later on. With the beginning of the "Naȳ kahän$\vec{\imath}$ " or "New Story" movement in the late 1950 s and early 1960s, however, this "primacy of the village" has been deliberately challenged. Especially early texts of the Naȳ kahān $\vec{\imath}$ genre are often set in somewhat remote or more peripheral small towns in North India and award particular attention to their specific socio-cultural makeup. Konrad Meisig, Erzähltechniken der Nayī Kahānī. Die neue Erzählung der Hindi-Literatur (Wiesbaden: Harrassowitz, 1996), 34; Madhu Singh, "Altered Realities, New Experiences: Bhisham Sahni, Nirmal Verma, and the 'Nayi Kahani' Movement,” Comparative Literature Studies 53.2 (August 15, 2016): 327 and passim. 
"shedding' light on the world from above" but as "emanating and illuminating it from within, thus transforming the world's visible and apprehensible contours." ${ }^{4}$ This also means that a wider scope for considerations of urbanity cannot end with the mere inclusion of urban experiences from outside the West but must involve a critical examination of the theoretical apparatus used to engage with these experiences. ${ }^{5}$ I want to contribute to this discussion by reading Naukar ki kamiz as advancing itself a theory of small-scale urbanity that is intricately tied to the specific narrative mode of the novel. In order to bring out the novel's theoretical potential for studies of urban spatiality, I will put it in a conversation with another set of writings on social space, namely those of Henri Lefebvre and Edward Soja, because this allows for a closer examination of the relationship between the representation and the production of social space that is at work in Shukla's novel. This is not an application of a prior existing theory to a literary text, however, but an attempt to offer one of several possible explications of the text through its imaginary intertextual relations. ${ }^{6}$

By reading the novel as a form of representation, production, and (theoretical) analysis of a small North Indian town and by highlighting the close interrelation of these three aspects, this article aims to provide two related but distinct arguments: First, the literary representation and analysis of the postcolonial small town in Naukar ki kamiz provides a useful theoretical apparatus and blueprint for the engagement with real and imagined, that is literary and nonliterary small towns. And second, in doing so, the novel contributes to broadening the concept of urbanity and to grounding it in the "reality" of everyday life so that it no longer stands for only one seemingly standardized form of the city, which has more often than not been uncritically imagined as the Western metropolis.

In its most basic understanding, the concept of urbanity relies on a simplified dichotomy between the urban and the rural or the city and the village in which the city represents the paradigm of progress and development and the village that of stagnancy and backwardness. Any form of settlement between these two extremes-such as the small town-is thus often neglected in studies on urban space. This is strongly connected to the inherent Eurocentrism of the field of urban studies that is not limited to a relative overemphasis on case studies from the West and the global north but has deeper structural reasons and implications. Jennifer Robinson's pointed remarks hold thus still

4 Prathama Banerjee, Aditya Nigam, and Rakesh Pandey, "The Work of Theory: Thinking across Traditions," Economic and Political Weekly 51.37 (September 10, 2016): 44.

5 Aya Hino, "Expatriating the Universal: A Decolonial Imagination beyond Authentic 'Asia," International Quarterly for Asian Studies 50.3-4 (2019): 31-54.

6 Although my reading of Shukla's novel partially deconstructs the theory/practice binary inherent to classical European notions of theory proper, this should not at all be taken as paradigmatic for South Asia traditions of thought. As Sheldon Pollock has shown, "the practice of theory in South Asia" - at least in classical Sanskrit literature-is instead characterized by a much more rigid distinction between theory and practice as compared to European notions of theory. Sheldon Pollock, "The Theory of Practice and the Practice of Theory in Indian Intellectual History," Journal of the American Oriental Society 105.3 (1985): 499-519.

7 Such a project of broadening the concept of urbanity is linked to what Kate Derickson-in following Dipesh Chakrabarty_calls "provincializing urban theory," that is, highlighting that the West is still the unacknowledged place of urban theory and as such strongly affecting its inner structure. Kate. D. Derickson, "Urban Geography I: Locating Urban Theory in the 'Urban Age," Progress in Human Geography 39.5 (1 October 1, 2015): 648. 
largely true today: "Understandings of city-ness have come to rest on the (usually unstated) experiences of a relatively small group of (mostly Western) cities, and cities outside of the West are assessed in terms of this pre-given standard of (world) city-ness, or urban economic dynamism." ${ }^{\text {A }}$ A similar dynamic is also at work within the field of literary studies on urban spaces, where "cities that are below the radar of Western metropolises and their canonized literature have remained largely out of sight." ${ }^{\prime 9}$ This is all the more remarkable since the small town has been a widespread albeit seldom discussed topos in literature and fiction more broadly. ${ }^{10}$ When non-Western urban spaces do find consideration in literary studies, this is usually confined to the "sprawling" capitals and megacities like Nairobi, Johannesburg, Mumbai, and Rio de Janeiro. ${ }^{11}$ What is still almost unexplored, however, are the specific conditions of non-Western, postcolonial small towns (as opposed to larger cities and megacities) and their imagination, reflection, and representation in literary texts. ${ }^{12}$

Due to its unique combination of representation, production, and analysis of social space, Naukar ki kamīz provides a powerful intervention in the field of (literary) urban studies. Where this is most visceral is in the minutely narrated scenes of everyday life that highlight the connection between space and power. My analysis of the novel therefore begins with a closer look at such real and imagined places of power and oppression in the first section, and then goes on to an examination of the slightly more abstract level of urban spatiality that Santu Babu comments on during his long walks through the town. This allows me to draw out the larger implications of the strong nexus between the production, the representation, and the analysis of social space in Shukla's text. In the last section, the article offers an analysis of the chronotopos or space-time of the novel itself, which provides the distinct framework for the narrative of Santu Babu's struggle. I

8 Jennifer Robinson, "Global and World Cities: A View from off the Map," International Journal of Urban and Regional Research 26.3 (September 2002): 531-32.

9 Lieven Ameel, Jason Finch, and Markku Salmela, eds., Literature and the Peripheral City (London: Palgrave MacMillan 2015), 1.

10 A widespread characteristic of literary small towns is their status as a microcosmos that is reflective of broader social developments and allows for their examination as if through a looking glass. For the role of small towns in literary productions and their neglect in literary studies, see Werner Nell and Marc Weiland, "Die erzählte Kleinstadt. Eine von der Forschung übersehene Größe? Themen, Texte, Zugänge," in Kleinstadtliteratur: Erkundungen eines Imaginationsraums ungleichzeitiger Moderne, eds. Werner Nell and Marc Weiland (Bielefeld: transcript, 2020), 9-57; Ryan Poll, Main Street and Empire: The Fictional Small Town in the Age of Globalization, The American Literatures Initiative (New Brunswick, NJ: Rutgers University Press, 2012). For a recently published anthology that includes several articles that discuss smaller cities and slightly more "peripheral" urban spaces around the globe, see Kerry Bystrom, Ashleigh Harris, and Andrew J. Webber, eds., South and North: Contemporary Urban Orientations ( Routledge India, 2018.

11 For a few particularly noteworthy examples regarding India, see Rashmi Varma, The Postcolonial City and Its Subjects (New York: Routledge, 2011); Shonaleeka Kaul, Imagining the Urban: Sanskrit and the City in Early India (London: Seagull Books, 2011); Vasudha Dalmia, Fiction as History: The Novel and the City in Modern North India (Albany: State University of New York Press, 2019); Rashmi Sadana, English Heart, Hindi Heartland: The Political Life of Literature in India (Berkeley: University of California Press, 2012). 12 In the Indian context, some work has been done on the literary and cultural significance of qasbas (a kind of small market and former garrison town). M. Raisur Rahman, "Qasbas as Place: A Sense of Belonging and Nostalgia in Colonial India," Journal of the Economic and Social History of the Orient 58.5 (2015): 672; Francesca Orsini, "Between Qasbas and Cities: Language Shifts and Literary Continuities in North India in the Long Eighteenth Century," Comparative Studies of South Asia, Africa and the Middle East 39.1 (June 19, 2019): 68-81. 
argue that it is the constant shifting between these registers of spatiality-the minute observation of everyday life on the one hand and Santu Babu's thoughts on space and power on the other - that constitutes the most radical potential of the novel for a literary analysis of social space, particularly for the task of rethinking global relationships as relationships between different kinds of social spaces.

\section{Real and Imagined Places of Power and Oppression}

Naukar ki kamizz tells the story of Santu Babu and his nameless wife through a chronicle of their sometimes eager and sometimes desperate attempts to lead a simple, but free, peaceful, and happy life. ${ }^{13}$ Like many of the obstacles and power dynamics that put the fulfilment of this goal more and more out of reach, the goal itself is also expressed through a spatial allegory: the couple's modest wish to go out for a walk together. The reasons for their inability to fulfill their wish are complex and manifold-the lack of a lock at the door, the lack of time, the fear that they will miss their visiting relatives or displease their employers/oppressors/benefactors. Most of these reasons, however, ultimately lead back to their social and economic exploitation. The power dynamics that enable this exploitation are also represented as spatially structured. And it is in the observation of the underlying spatial conditions of power that Santu Babu achieves a critical consciousness of his own exploitation. Even more crucially, it is also in this observation of space that the novel locates the possibility of resistance to the mundane forms of everyday oppression.

The two central figures that stand for the couple's oppression and social dependency are the Sahib, the boss of Santu Babu's government office, and the Soctor, who is also the couple's landlord and provides a kind of dubious "protection" in exchange for the unpaid "help" of Santu Babu's wife, who gradually takes over most of the work in the Doctor's household. The Sahib and the Doctor both live in big bungalows that make their owner's power felt even when they themselves are not present. Although the Sahib's bungalow stands at quite a distance from the office compound, there seems to be a mysterious connection between the two places that highlights the peculiar status of the bungalow as a seat of power-at once directly related to the office and yet independent from it. This is discernible, for example, through the Sahib's and his servant Mahangu's ability to be present at the office and the bungalow at the same time. ${ }^{14}$ Santu Babu notices this on a trip to the Sahib's bungalow, where he had cycled to from the office: "I was surprised that Mahangu was at Sahib's house. He had not overtaken us on the road. How had he travelled here?"15

It is not only the spatial relationships of the Sahib's bungalow that reveal much about the power dynamics in the novel. The same can be said about the house of the

13 Because this article is exclusively concerned with the spatial dimension and the explorations of everyday life in the novel, I refrain from giving a more detailed account of the content and plot. For a narratological analysis of the novel, including a discussion of the absurdist and existentialist elements along with a brief plot summary, see Martin Christof-Füchsle, "Indianness, Absurdism, Existentialism, and the Work of Imagination: Vinod Kumar Shukla's Naukar kī kamīz," in Imagining Indianness: Cultural Identity and Literature, eds. Diana Dimitrova and Thomas De Bruijn (Cham: Palgrave Macmillan, 2017), 131-45.

14 Shukla, The Servant's Shirt, 128.

15 Shukla, The Servant's Shirt, 131 [133]. 
Doctor too. Like the Sahib's house, it is enclosed by a compound wall and thus is separated from the outside as well as from the small hut that Santu Babu and his wife rent from the Doctor. Interestingly, though, the wall has a gap that leads directly to the backyard of the couple's hut, thus establishing a connection between the two otherwise separate places. This cleavage and the fact that the Doctor's bungalow lies on higher ground than the house of Santu Babu and his wife is not only of symbolic significance but has direct consequences as well:

\begin{abstract}
It rained continuously for three days. The area in the back of our house was knee-deep in water. The rubbish from the doctor's compound floated across the break in the boundary wall. The wall must have been broken deliberately to let the water out. The municipal drain intended for the overflow was stopped up. If only we could seal the boundary again. ${ }^{16}$
\end{abstract}

Santu Babu suspects that the Doctor made a whole in the brick wall between their compounds so that the water would flow out of the Doctor's garden and right into that of Santu Babu and his wife. Because of the whole in the wall, the two of them are not only knee deep in water but also have to fend of all the "rubbish" (कूड़ा-कर्कट; literally "rubbishdreg" or "filth-sediment") that literally and metaphorically arrives from the Doctor's side. The whole novel can be seen as an account of how the young couple tries to cut or seal the connections that they have somewhat rather incautiously established between themselves on the one hand and the Doctor and the Sahib on the other-connections that threaten to take their lives more and more out of their own hands and fill it with duties and obligations, in very much the same way as their backyard gets filled up with the Doctor's rubbish.

The influence of powerful people-who are not the source but part of the social power structure-not only exerts itself on the private space of the couple but also on other spaces. It cannot exert itself without resistance, however. Within the narrative of the novel, the disobedient or resisting momentum of a certain space is most regularly located within its metaphysical or "imagined" sphere. The spatial logic of the government office, for example, fails to fully assert itself on the space it occupies because of the presence of contesting representations of the same space, which are again tied to spatial practices. Religious practices are among the most powerful of such contesting representations in Naukar ki kamiz. Be it the small office room that stays completely empty out of respect for the sufi saint whose grave lies on the premise ${ }^{17}$ or the Hanuman statue in the main room that draws a whole family into the office and thus disrupts the order of the workplace:

One day a farmer and his extended family entered the hallway bearing sticks of incense and a ritual coconut. They stepped past tables and chairs all the way to the Hanuman statue. The orderlies and babus failed to stop them... . The babus told the farmer to hurry up... . They moved tables aside to make room for the devotee and his family. The farmer offered flowers to Hanuman and distributed mithai to the office staff... . 
The sahib was displeased when he heard of the episode. He wanted the Hanuman statue moved out and established somewhere on the grounds but nothing came of his instructions. $^{18}$

The orderlies fail to fully impose the secular order of the office as the sacred dimension of the space reasserts itself through the invasion of the incense bearing and coconut wielding farmer's family. With the help of his devotees, Hanuman even moves the office tables and reestablishes his precarious presence so that nothing comes out of the plan to move his statue out for good.

A different kind of nonmaterial or "imagined" aspect of space can be found in Santu Babu's imaginations or daydreams. For him, this layer of imagination allows him to endue the space he inhabits with his own meaning, which enables him to make sense of his circumstances and to ultimately fight against or simply flee from the oppressive relationships that make his life so difficult. The lack of opportunity to spend time together with his wife is therefore also mainly perceived through spatial metaphors that allow Santu Babu to express his discontent. It finds its culmination in the mental image of two separate doors with two separate locks to his house-one for his wife and one for himself. This transforms their shared space into two separate places, and even though they are both trying to get back to the same shared space of security and happiness, the gendered circumstances and their entanglement in their work relationships make it impossible to perceive the shared hut as a shared home: "Our efforts had yielded results but a transparent separation stood between us through which we came and went as from one room to another." 19 In the end, it is this separation from her husband and their shared house that leads to the defiant declaration of the wife who relieves herself of the work in the Doctor's bungalow: "I am not a bonded slave. If the watchman calls for me I will refuse to go." 20

The idea that space is to a very large extent defined by our mental representation of it is central to Henri Lefebvre's theory of space and its later adaption in the work of Edward Soja. ${ }^{21}$ Both have argued that a place can only be understood as the interplay of its material and mental aspects, which profoundly influence each other. Naukar kī kamīz shows how this mutual influence plays out in everyday life: the materiality of space limits and structures the way in which Santu Babu perceives the space, but the mental images of the space he inhabits also allow him to contest and change the material restrictions. ${ }^{22}$

18 Shukla, The Servant's Shirt, 67 [69].

19 Shukla, The Servant's Shirt, 205 [209].

20 Shukla, The Servant's Shirt, 215 [219].

21 Henri Lefebvre, The Production of Space (Oxford: Blackwell, 1991); Edward W. Soja, Thirdspace: Journeys to Los Angeles and Other Real-and-Imagined Places (Cambridge, MA: Blackwell, 1996), 6.

22 As Martin Christof-Füchsle argues, the act of imagination is thus not simply a form of escapism that provides a break from the everyday reality, but opens up a space for the development of Santū Babu's agency: "When using imagination creatively, one does not only flee from reality, leaving behind the oppressive status quo, but creates a space for oneself, one's own individuality. Santū is now able to face life afresh and to finally throw off the servant's shirt, tear it to shreds, and burn these... . Thus, the protagonist not only comes to see the world differently but becomes aware of the inherent possibility to make his own choices, to become, idealiter, the author of his own life." Christof-Füchsle, "Indianness, Absurdism, Existentialism, and the Work of Imagination: Vinod Kumar Shukla's Naukar kīkamīz," in Diana Dimitrova and Thomas Bruijin's Imagining Indianness: Cultural Identity and Literature, 141. doi: 10.1007/978-3-319-41015-9.141. 
The novel's presentation of this two-sided interdependency is not a neutral depiction of two equal aspects, however, but marked by a considerable preference for the mental aspect of space as the locus of resistance against the oppressive structures of materiality. If the same distinction is applied to the novel itself, it becomes a playing field for a very real analysis of imaginary spaces and thus even a means of learning to come to terms with the real world outside the novel. Shukla explicitly mentioned this function of literature in an interview: "We want to run away form the murderers and from the tangles with the police. But when we encounter the same event on the stage our strength to face whatever is happening seems to grow. Reality breaks us; art seems to give us strength to face what we fear." 23 One of the most pronounced means for a possible resistance against oppressive spatial structures that the novel provides is its model of spatial analysis that although presented in the fictional setting of the novel also hints toward the possibility of its real-world application. It is this specific form of spatial analysis in Naukar kī kamiz that I now turn to.

\section{A Rhythmanalysis of a Small North Indian Town}

The narrator, Santu Babu, quite explicitly links the oppression of the everyday-the sense of confinement and perpetualness that he and his wife experience-to the smallness and confinement of the small town he lives in. And it is here, in the specific way that Santu Babu's experiences and observations make the small town analytically accessible, that the novel's portrayal of social space provides the literary critic or theorist with the most practical tool for a reconsideration of literary urbanity and urban spatiality. The most crucial aspect of this can be found in the novel's emphasis on the category of the everyday. This emphasis introduces a notion of unchanging perpetualness that is not characterized by an enduring continuity but a constant recurrence. The small town, it appears, does not so much persist in time but rather continues to occur every day through the endless repetition of everyday life. In the narrative, this plays out as reoccurring conflict between change and repetition as Santu Babu and his nameless wife are caught between their conflicting desires for change and continuity. They want to preserve everything that is good in their life-their intimate relationship, the peace and quietness of private life in their small town-but they also want to escape from the daily struggle of making ends meet and securing their social status. In order to sustain their happy life, though, Santu Babu has to keep on playing by the rules. He wants to leave the difficulties behind, but there is nowhere he could turn to instead:

The only way out was to quit the field. Was quitting the field the same as quitting the house? In that case why did I feel defeated even when I was returning from the outside? Clearly, my sleeping and waking, my going and coming, my walking about on the road-all these were part of quitting the field. I did not wish to leave the field forever. All I knew was I could not stay inside too long, nor could I dawdle outside. When I left, I wanted to stay away indefinitely. I also wanted that the scene inside should repeat when I returned: my wife carrying a bucket of water, my mother winnowing rice. Even if I had been away an eternity I

23 Satti Khanna, "Introduction," in Vinod Kumar Shukla's The Servant's Shirt (New Delhi, London: Penguin, 1999), xii. 
wanted everything to repeat the way it was this moment-this house, this cup tipped over on the floor. Well, not everything, not the cobwebs on the walls, nor the fly that alighted again and again on my wife's foot. I wanted the rings around my wife's eyes to vanish. I wanted my wife and mother infinitely happy. I would not have objected to the house being freshly whitewashed. ${ }^{24}$

Two different forms of infinite temporal duration are at work here. Santu Babu wants to break out from the confinement of his home and looks toward the ever-changing "eternity" (अनंतकाल) that lies outside the field and the house. He does not want to stay away "forever" (हमेशा-हमेशा) - just long enough to experience some form of change. At home, however, time should not continue indefinitely but rather persist in repeating itself "again and again" (बार-बार), "just as it is now" (बिलकुल अभी जैसी). The solution-to keeping everything as it is and still allowing for some experience of change and transformation-seems to lie in movement. His walking, his going and coming, constitutes a part of what Santu Babu calls quitting the field and leaving the house. But outside the field there is only the small town, which cannot provide the form of eternity that Santu Babu is looking for. Instead, he returns home far earlier than planned: "I had to find a reason to stay away indefinitely and all I had was a small town, which I could cover from one end to the other in half an hour." 25 The same smallness and perpetuity that Santu Babu perceives as restricting, however, also becomes the very reason for him to take recourse in his imagination-simply because there is nowhere else he could turn to. This space of imagination is where he draws his strength from to endure and resist the oppressions of the everyday. Additionally, it is the very confinement of the home and the small town that makes Santu Babu go on his tour around the town. Precisely because he has nowhere to go, he keeps on leaving the house and returning to it while developing his spatial consciousness and the social critique connected to it quite literally on the way. It is therefore the particular characteristic of the small town-its perpetuity of a lesser emptiness - that makes it uniquely conducive for the development of a spatial consciousness in its inhabitants and for the imaginative (and in this case literary) production of other places that allow for an escape from the confinement and repetitiveness of everyday life.

Throughout the novel Santu Babu acts as the first-person narrator and the principal protagonist of the story. Even though other persons do speak in the novel, the reader can never be entirely sure whether their speech is reported correctly by the narrator because Santu Babu seamlessly moves between the narration of things that (allegedly) actually happened and his own speculative conjectures or imaginations of alternative realities. What often works as a form of imaginative resistance to the oppressive structures of everyday life quickly becomes a way of ventriloquism that effectively silences the voice of his wife, who's lack of a proper name seems symptomatic in itself. Although Santu Babu clearly perceives their oppression as a shared condition and wants his wife to be "infinitely happy," he also shows a lack of comprehension and interest for the specific forms of gendered work and exploitation (indefinitely carrying a bucket of water and winnowing rice) that his wife and mother endure. As in the previously quoted

24 Shukla, The Servant's Shirt, 7-8 [13]; translation slightly adapted.

25 Shukla, The Servant's Shirt, 8 [14]. 
paragraph, he even seems to regard the repetition of their work as a basis for his own temporary relieve-quitting field and house and the possibility of a successful return. ${ }^{26}$

Especially in the first part of the novel, Shukla spends much time on the description of the activities and specific rhythms of everyday life in the town. By devoting attention to small incidents and the significance they have for the affected people, Shukla paints an incredibly lively picture of the town. Interestingly, it is precisely the seemingly dull facts - often even appearing as numbers or measurements-that provide the details that bring the scenery of the novel so close to the reader. In one instance, for example, the sleepless Santu Babu walks through the poor neighbourhood of the low-caste Satnami community at night:

It was dark in the satnami quarter. To be sure, there was a light pole but no bulb in the socket.... The blind pole was stuck in the ground as a marker of absolute darkness. Every six months a new bulb was fitted into the street light. Every six months children threw stones at the bulb. A few men and woman watched the stone throwing, interested to see which child would hit the bull's eye. The elders sitting by their huts did not scold the children. The may have imagined that in the dark neighbourhood a single street light was a joke. ${ }^{27}$

In the low-caste neighbourhood the sole sign of public support and financial contribution is a single light pole. What is already merely a joke is made even more explicit through the instantaneous demolition of every newly fitted light bulb. Due to the lasting inaction of the government that fails to facilitate lasting social change, the pole brings no light into the neighborhood but, "like a beam of darkness" (अंधेरे के मयाल की तरह), serves only to mark the social exclusion to which the community remains condemned. Shukla shows how conflicts of different social practices originating from and belonging to different spheres of society-imbued with or cut off from forms of political powermanifest themselves through interfering rhythms. The rhythm of attending to the assumed needs of a community by replacing the bulbs in the street lamp in their neighborhood is disturbed by the immediate disruption of the desired effect. Interfering rhythms can thus constitute possible disturbances in the exertion of political power or at least point toward the cynical gestures at their heart.

It is through the attention to these rhythms and their disturbances that Vinod Kumar Shukla becomes what we could describe with Henri Lefebvre and Catherine Régulier as a kind of literary rhythmanalyst. ${ }^{28}$ The term marvelously captures the central dimension of spatiality in Naukar ki kamiz - the significance of everyday life, which is also at the very heart of the concept of rhythmanalysis. As Lefebvre and Régulier suggest, and as Shukla demonstrates in his novel, it is by drawing the attention to the rhythms of everyday life in cities and other social spaces that we become more attuned to the

26 I want to thank Charlotte Bomert for alerting me to this point.

27 Shukla, The Servant's Shirt, 25 [29-30].

28 Although the term rhythmanalysis was first proposed by Lucio Alberto Pinheiro dos Santos (in 1931) and further developed by Gaston Bachelard, it gained wider recognition only with the works of Henri Lefebvre and Catherine Régulier (from 1985 onward) and particularly with the publication of the essay "Elements of Rhythmanalysis" (originally published in French as "Éléments de rythmanalyse" in 1992). 
manifold concrete differences of spatial phenomena. ${ }^{29}$ A greater attentiveness to rhythms also allows one to conceive space as intimately connected to and produced in and through time. On a more abstract level, the attention to the segmentation and cyclical repetition of time through rhythms (a category hitherto neglected in the history of philosophy, as Lefebvre claims) leads to a more thorough understanding and critique of "the process of thingification (of reification)" that enables the "production" of things and everyday reality in time and space. ${ }^{30}$ All these aspects are already abundantly present in Naukar ki kamiz. It is, however, the role of Shukla as the author that comes particularly close to the work of the rhythmanalyst, who Lefebvre envisages as someone still to come: "He will listen to the world, and above all to what are disdainfully called noises, which are said without meaning, and to murmurs [rumeurs], full of meaningand finally he will listen to silences." 31 This is exactly what Shukla does, as Satti Khanna, the translator of Naukar kī kamīz, makes clear when he recalls how Shukla prompted him to listen to the various sounds of everyday life-an old man chanting a lullaby or a woman pumping water with a handpump-while taking him on a tour around the city of Raipur. ${ }^{32}$

Although the category of space seems somewhat negligible at first, rhythmanalysis actually relies very much on an understanding of social space as a very distinct form of social product. The social practices (and the rhythms in which they reappear over time) described in Naukar ki kamiz are all tied to the specific place where they are encountered. The government office where Santu Babu works, the Sahib's bungalow, the Doctor's house, the streets in the town or Santu Babu's own home, they all enable or impede specific forms of social practices and at the same time their meaning as a social space gets produced through these practices. Nothing exemplifies this better than Santu Babu's thoughts about the meaning of home right at the beginning of the novel:

\begin{abstract}
A house is not so much for leaving from as for returning to. For going out there are other people's houses... . But for coming back, a home is essential even if it is a single rented room, or a room shared with other tenants.

For my wife the house was not so much a place to come out from and therefore it was not so much a place to go back to. If she ever went out, she returned home soon. Living alone one has to lock up the house, but if one's wife, or parents or brothers or sisters are in the house, one can leave without locking up. ${ }^{33}$
\end{abstract}

Space changes according to social practice, and therefore the house or the home (धर) means something quite different to Santu Babu's wife than what it means to him. The lived space of the shared house (as any other space as well) is thus also an inherently gendered space. Although Santu Babu perceives the house as a base to which he returns,

29 Deirdre Conlon, "Fascinatin' Rhythm(s): Polyrhythmia and the Syncopated Echoes of the Everyday," in Geographies of Rhythm: Nature, Place, Mobilities and Bodies, ed. Tim Edensor (Farnham: Ashgate, 2010), 71-74.

30 Henri Lefebvre, Rhythmanalysis: Space, Time, and Everyday Life (London and New York: Continuum, 2004), 1 .

31 Lefebvre, Rhythmanalysis, 19.

32 Khanna, "Introduction," xii.

33 Shukla, The Servant's Shirt, 1 [7]. 
his wife mostly stays within the house (presumably "carrying a bucket of water" or indefinitely "winnowing rice") and thus perceives it in very different terms. Here again, though, it seems obvious that what is presented as the "perceived" space of the wife is actually projected or imagined by the narrator/husband and based upon his own desires and interests. In any case, however, the text makes it clear that the perception of a specific space is closely related to the way the space is produced through specific social practices. In the course of the novel, though, Shukla does not just leave it at that, but exposes the mechanisms that produce and reproduce the conditions for the social practices that shape the social spaces we inhabit.

The reader "experiences" the town as a lived space, as the sum of the various places described from a micro-perspective. In Lefebvreian terms, this means that the focus of the narrative is on the perceived and the lived aspect of space, or that we are primarily told about spatial practices and spaces of representation. ${ }^{34}$ Occasionally, though, Shukla also offers a macro-perspective on the space of the town, and in these instances the town is conceived as a certain kind of representation of space (the terms used in the English translation of Lefebvre). Unlike the very immediate view on social practices positioned at the same level as the protagonists in the novel themselves-as Khanna observes in the introduction ${ }^{35}$ - the macro-perspective is a view from above, focusing on abstract relationships. It is this view that, as Lefebvre notes, produces the representation of space as the space of capital and power. ${ }^{36}$ This also becomes very clear from Santu Babu's reflections on the different geographies of town and village. He notes the essential function of the police station and its strategic position in the town and draws our attention to the social structure underlying the town's geography:

In the settling of a town care was taken that right in among the jewellers and traders and financiers there should be a police station: jewellers and traders and financiers had much to be afraid of... . Many people found it difficult to live in town without assurance of security. At the other end of the road from the main police station lay the neighbourhood of the Muslims.... In the settling of a town no attention is paid to caste, but the extent of poverty is important. The poorest people live the farthest from the centre and their neighbourhoods are the dirtiest. ${ }^{37}$

What seems particularly noteworthy in this quotation is the relationship between deliberate planning (in the "settling/inhabitation" [बसावट] "care was taken" [ध्यान दिया जाता था]) and seemingly involuntary emotions (the fear of the traders and their need for security) that together produces this representation of space. The quoted paragraph also highlights that power relations and social inequality have a complex spatial dimension: the police station is right between the Muslim neighborhood and the jewelers, and the extent of poverty increases with the distance from the city center. Power

34 Lefebvre, The Production of Space, 38-39; Soja, Thirdspace, 65-ff.

35 Khanna, "Introduction," ix.

36 "Representations of space ... are tied to the relations of production and to the 'order' which those relations impose, and hence to knowledge, to signs, to codes, and to 'frontal' relations." Lefebvre, The Production of Space, 33.

37 Shukla, The Servant's Shirt, 86 [87]. 
relations and structures of economic inequality are thus not represented as secondary to the social space of the town but instead as quintessential aspects of the production of this social space in the first place. The original Hindi text is even more precise in this regard: what is important for the "inhabitation" (in Khanna's translation "settling") of the town is not only the "extent of poverty" but the very fact of poverty itself "गरीबी शहर की बसावट में बहतत महत्वपूर्ण होती थी।" (Poverty is very important in the inhabitation of a town). ${ }^{38}$

The distanced view from above onto the conceived space of abstract relations also looks at the relationship between the town and the wider national or global space through the network of roads and train lines that connect the small town with the global market of goods and ideas. Santu Babu experiences this relationship mainly as a one-way connection. Products, ideas, and information come to the town, but nothing leaves from there. ${ }^{39}$ Although he knows the air fares between Bhopal and Delhi and "all the conveniences offered by the Oberoi-Continental in Bombay," ${ }^{40}$ he can hardly afford to take a day off from work to visit his brother in a nearby town. The sphere of the town and that of the global market are only loosely connected by the trucks that pass through on their way to Calcutta on National Highway 6. For Santu Babu himself, who knows of their interdependence in theory, they remain utterly separate in practice. This reminds the reader that even in times of a newly emerging mobility global social space is structured in more complex ways than the dichotomy of center and periphery suggests. The town in which Santu Babu lives is neither central nor peripheral; it is directly linked to the emerging flow of capital but nonetheless marked by the bitter amalgam of standstill and continuity.

The depiction of everyday life in a small town and the meticulous and yet poetic description of its rhythms provides the basis for a comparison and reassessment of the space-time structures of the various different places connected within a seemingly tightknit global space. ${ }^{41}$ What motivates and enables this description in the first place, however, and makes Santu Babu go on his extended tours around the town, is in no small part the very same combination of confinement and perpetualness that sit the root of what he experiences as the oppressive structures of social relations. It is through the analysis of the social rhythms in the town and the broader spatial consideration that follow it that Santu Babu can come to terms with his own social status and begin to question it. Just as the narrative produces its specific social spaces through the observation of its main character, so the novel Naukar $k \bar{\imath} k a m \bar{\imath} z$ can itself be seen as a literary blueprint of a rhythmanalysis that functions as a tool for social change. Seen from the standpoint of Lefebvre and Régulier, Vinod Kumar Shukla thus personifies the very idea of a poet who brings about change because he observes. The observation and the representation of the observed are then already the very change of which it is the

38 Shukla, Naukar K̄̄ kamīz, 87; my translation.

39 The inhabitants of Santu Babu's small town can thus be understood as akin to those who Doreen Massey described as "simply on the receiving end of [a global] time-space-compression." Doreen Massey, "A Global Sense of Place," Marxism Today (June 1991): 26.

40 Shukla, The Servant's Shirt, 11-12.

41 As Lefebvre notes, rhythms have to be put into a relationship with each other in order to gain meaning. Lefebvre, Rhythmanalysis, 10. 
precondition as well. It is here, where the aim of a writer like Shukla and that of the rhythmanalyst coincide:

The rhythmanalyst could, in the long term attempt something analogous [to the aim of the poet]: works [oeuvres] might return to and intervene in the everyday. Without claiming to change life, but by fully reinstating the sensible in consciousnesses and in thought, he would accomplish a tiny part of the revolutionary transformation of this world and this society in decline. Without any declared political position. ${ }^{42}$

\section{Conclusion: The Small Town as a Real and Imagined Space}

Through the descriptions of rhythms and social spaces in Naukar ki kamiz, Shukla reinstates a sensible consciousness for a broadened spectrum of urbanity and for how spaces are constituted and reproduced through social practices. This can quite rightfully be understood as "a tiny part of the revolutionary transformation" that Lefebvre is talking about. In taking different layers of spatiality (real and imaginary) and social rhythms as a necessarily intertwined starting point for a literary analysis of urban space (an analysis through literature as well as of literary texts), Shukla compels us to perceive the postcolonial small town not as an anomaly or a deviation of the Western metropolitan norm but as a specific form of urbanity in its own right. To understand how the novel accomplishes this, we need take a closer look at the relationship between the representation and the literary (re)production of the small town in the text.

Like any novel, Naukar ki kamīz has its own spatio-temporal structures that govern the inner logic of the narrative and enable the production of the specific form of "knowledge" that the narrative constitutes. In the case of Naukar ki kamiz, the governing principles of the narrative, which enable the unfolding of all the specific places and their meanings and correlating practices, can be described as the chronotope of the postcolonial small town. According to Mikhail Bakhtin, "All the novel's abstract elementsphilosophical and social generalizations, ideas, analyses of cause and effect-gravitate toward the chronotope and through it take on flesh and blood, permitting the imaging power of art to do its work." 43 The narrative of the novel and especially its spatial representation are only possible in the specific time-space relationship established through the chronotope. Santu Babu's feeling of confinement while he longs for really being at home in his house (which for him includes the possibility of going for a walk with his wife); the couple's relationship to the Doctor and the Sahib-hierarchically distant and still emotionally and spatially closely connected; the layout of the town that reflects and shapes the social position of Santu Babu; all this is possible only in the deliberate construct that the chronotope of the postcolonial small town represents.

In other words then, what is at work in Naukar ki kamiz is an analysis of the postcolonial small town through its literary production. The analysis of the town is thus inseparable from the construction of the town in the literary text. It is also in another

42 Lefebvre, Rhythmanalysis, 26.

43 Mikhail Mikhaulovich Bakhtin, "Forms of Time and of the Chronotope in the Novel," in The Dialogic Imagination: Four Essays, ed. Michael Holquist, trans. Caryl Emerson and Michael Holquist (Austin: University of Texas Press, 1981), 250. 
sense then that the fictitious town of the novel is real and imagined at the same time. It is a self-reflexive construction of a very specific kind of chronotope that explicitly involves the analysis of its own constructedness and social conditionality. The very confinement and perpetualness that along with its location characterizes the chronotope of the postcolonial small town in the novel makes the examination of its own contingency to appear as an almost inevitable consequence. The spatial analysis of the protagonist therefore becomes an almost quintessential part of the chronotope itself. It is particularly interesting in this context that the small town of Naukar ki kamiz remains anonymousunnamed and without any identifying characteristics-throughout the narrative. Although this is not at all unusual for literary representations of small towns, it is particularly relevant here because it highlights the transferability and broad applicability of the novel's own spatial theory. ${ }^{44}$

Insofar as the chronotope of the small town in the novel is based on the observation and (rhythm)analysis of very real relations of social oppression, it constitutes a specific spatial episteme that not only governs the literary space of the novel but implicitly claims to be also constitutive of the real social space of the small town outside the literary text. Although Bakhtin's own writing on the chronotope seems to endorse such a transferral of the analytical possibilities of the concept of the chronotope to an engagement with "the real world" outside the novel, ${ }^{45}$ Lefebvre is very explicit in his scepticism about the idea that literature could produce knowledge about space simply because any given social space cannot be reduced to a message that could be deciphered or "read." ${ }^{46}$ In order to assert my reading of Shukla and Lefebvre against Lefebvre himself, as it were, I therefore need to return to the work of Edward Soja. As Soja points out, any form of writing about social space-that of Lefebvre himself included-can only provide a discourse on and a reading of space instead of a lived knowledge or what Lefebvre called "inhabiting" space. There is thus no difference between literature and "theory" in this regard and therefore no reason why a novel could not develop a "theoretical" knowledge about space. According to Soja, what allowed Lefebvre to develop a more pluralistic and decidedly social understanding of spatiality was precisely not his theoretical detachment but his polyphonic bricolage of constantly changing notions of social space that made it impossible to establish any kind of closed epistemology of spatiality based on the binary distinction of mental/material or real/imagined. This is what Soja calls "thirding-asOthering" and describes as the "first and most important step in transforming the categorical and closed logic of either/or to the dialectically open logic of both/and also." 47 $\mathrm{He}$ argues that this "produces what might best be called a cumulative trialectics that is

44 That small towns often remain unnamed is certainly true for various literary genres and traditions. It might be even more common in Hindi literature due the lasting influence of the Nayī Kahānī movement, which was concerned with a certain sense of alienation and "uprootedness" and thus often located the narrative in an unnamed, medium-sized provincial town. Singh, “Altered Realities, New Experiences," fn 53; Meisig, Erzähltechniken der Naȳ̄ Kahānī.

45 Bakhtin refers to "a real life chronotope of meeting" in "organizations of social and governmental life," for example, and acknowledges the intricate relationship between literary chronotopes and extraliterary spaces. Bakhtin, "Forms of Time and of the Chronotope in the Novel," 99, 254.

46 Lefebvre, The Production of Space, 7.

47 Soja, Thirdspace, 60. 
radically open to additional othernesses, to a continuing expansion of spatial knowledge." 48

From here it is only a tiny step to return to Naukar kī kamizz and to Santu Babu's constant gliding and shifting between the imagined and real spaces of his life and the small town he lives in. The novel portrays and performs a thirding-as-Othering on several different levels. Not only is there a persistently simultaneous presence of the imagined and real aspects of space within the novel itself, such as when Santu Babu links the material presence of his house directly to his and his wife's perception of it. There is also a continuous bricolage of the reported experience of everyday life in a small town together with the seemingly impersonal and detached observation of the rhythms, sounds, distances, connections, and movements that constitute the specific configuration of time and space-the chronotope-that enables the reproduction of this everyday life. As such, the chronotope of the postcolonial small town is characterized by its location-neither central nor peripheral-and by its temporality-a peculiar combination of slowness and perpetualness - connected to the fast-paced global development and still seemingly changeless and constant. In the end, however, the novel shows that such an approach to social space as a thirding of the hitherto given binary scale is not only about the expansion of spatial knowledge in order to include the specific characteristics of small-scale urbanity in the global south (although it is about that as well), ${ }^{49}$ but also about learning new ways of inhabiting and shaping the space that defines us. In this sense, then, social space is similar to the servant's shirt (naukar kì kamīz) that Santu Babu is forcefully made to wear by the oppressive Sahib. The servant's shirt shapes his wearer and defines his role as a servant, but when Santu Babu slowly becomes aware of this function of the shirt he goes on to shred it into pieces and eventually also burns it, thus finally setting himself free.

48 Soja, Thirdspace, 61.

49 Soja emphasizes this aspect by devoting a chapter of his book to the postcolonial critique of social space. Soja, Thirdspace, 125-44. 